\title{
A Psycholinguistic Study of Political Rhetoric of Fear
}

\author{
Badriah Khalid Al-Gublan ${ }^{1} \&$ Linda J. Rice ${ }^{2}$ \\ ${ }^{1}$ Applied Linguistics Department, College of Languages, Princess Nora University, Riyadh, Saudi Arabia \\ ${ }^{2}$ Ohio University, Athens, OH, USA \\ Correspondence: Badriah Khalid Al-Gublan, Professor of Applied Linguistics, Applied Linguistics Department, \\ College of Languages, Princess Nora University, Riyadh, Saudi Arabia. E-mail: bkalgublan@pnu.edu.sa
}

\author{
Received: June 18, $2020 \quad$ Accepted: July 30, $2020 \quad$ Online Published: September 23, 2020 \\ doi:10.5539/ijel.v10n6p245 URL: https://doi.org/10.5539/ijel.v10n6p245
}

\begin{abstract}
Political campaigns are dynamic struggles between candidates to define the informational context for voters. Early studies (Kaid, 1981, 1994a, 1994b) suggested that political advertising has cognitive and behavioral effects on voters. It communicates the brand promise of a candidate blending functional and emotional benefits that voters gain from their relationships with a candidate.

This study, based on Lakoff's Framing Model (LFM, 2004), proposes a pragmatic model for the analysis of a political election rhetoric. Within this pragmatic model, it is shown that in such a rhetoric the process of choosing variables of mental and psychological strategies is used. Such a process can be understood as the outcome of producers' choice making, dynamic negotiation and linguistic adaptation. The analysis of a political discourse makes it possible to see how frames are powerful rhetorical entities that motivate audience to filter their perceptions of the world. It presents evidences to the claim that a candidate's speech using 'rhetoric of fear' appeals to the audience. Contradicted reactions appear: some audience react feeling 'fearful' while others respond feeling 'protected' or 'heard' that a candidate is listening to their concerns and willing to fulfil them. It also shows how the institutionalized use of strategy language has implications: some of these emerge from the genre itself while others derive from situation; specific choices.
\end{abstract}

Keywords: political rhetoric, framing theory, politics of fear, liberals, conservatives

\section{Introduction}

Politics is a struggle for power in order to put certain political, economic and social ideas into practice. In this process, language plays a crucial role. A political action is prepared, accompanied, influenced and played by language. In this season, in which the United States is highly engaged with presidential campaigns, the shaping of arguments to appeal to the citizens is charged. Each of the major political parties, Democrat and Republican, is writing rhetoric to shape arguments to appeal to voters' hearts and minds. Media Republican show presidential nominee Donald Trump's speech in which he formally accepted the nomination, writing that it was "intended to instill fear and terrify people," that it painted the U.S. as a "dystopia" and a "land of horrors".

\subsection{The Objective of the Study}

The research aims at conducting a psycholinguistic study of a political candidate's rhetoric of fear in his presidential election speech within the framework of Lakoff's LFM. It intends to examine how Language is influenced of such "frames", to shape his audience's thought and behavior.

\subsection{The Significance of the Study}

This study tackles a variety of language, i.e., a political language used in a specific context in the domain of different disciplines: applied linguistics; in the level of semantics, pragmatics, stylistics and psychology.

\subsection{Limitations of Study}

The study is a psycholinguistic analysis of the Nomination Acceptance Speech of the candidate, Donald Trump, and the reaction of the Editorials after the acceptance of his speech, from major news sources (e.g., Wall Street Journal, New York Times, and Washington Post) within the framework of LFM.

\section{Literature Review}

The related studies reviewed are classified into two categories: the first is studies on Trump's use of 'politics of 
fear' and the second on the LFM proposed by Lakoff.

\subsection{Studies on Trump's Use of 'Politics of Fear'}

\subsubsection{Lakoff's Books and Articles}

In Moral Politics (2002, pp. 143-176), 'It is a blend of cognitive science and political analysis. It considers the conceptual metaphors that Lakoff sees as present in the minds of American "liberals" and "conservatives". Lakoff argues that the differences in opinions between liberals and conservatives follow from the fact that they subscribe with different strength to two different central metaphors about the relationship of the state to its citizens. Both, he claims, see governance through metaphors of the family. Conservatives would subscribe more strongly and more often to a model that he calls the "strict father model" and has a family structured around a strong, dominant "father" (government), and assumes that the "children" (citizens) need to be disciplined to be made into responsible "adults" (morality, self, financing). Once the "children" are "adults", though, the "father" should not interfere with their lives: the government should stay out of the business of those in society who have proved their responsibility. In contrast, Lakoff argues that liberals place more support in a model of the family, which he calls the "nurturant parent model", based on "nurturant values", where both "mothers" and "fathers" work to keep the essentially good "children" away from "corrupting influences" (pollution, social injustice, poverty, etc.).' (Lakoff, Wikipedia, the free encyclopedia)

In Don't Think of an Elephant: Know Your Values and Frame the Debate, Lakoff (2004) explains 'how conservatives think, and how to counter their arguments. He outlines in detail the traditional American values that progressives hold, but are often unable to articulate. He also breaks down the ways conservatives have framed the issues, and provides examples of how progressives can reframe the debate.' (Lakoff, Wikipedia, the free encyclopedia)

In Thinking Points: Communicating Our American Values and Vision, Lakoff (2006) 'not only offers a deep understanding of the progressive worldview, but also reveals the nature of the so-called political center.' (Lakoff, Wikipedia, the free encyclopedia)

In The Political Mind: Why You Can't Understand 21st, Century American Politics with an 18th century Brain, Lakoff (2008) 'spells out what cognitive science has discovered about reason, and reveals that human reason is far more interesting than we thought it was.' (Lakoff, Wikipedia, the free encyclopedia)

In Metaphors We Live By, Lakoff and Johnson state (1980) that 'metaphors are not just matters of language, but are used extensively in reasoning and understanding. Typically, an abstract domain is understood metaphorically in terms of a more concrete domain. To a large degree, they argue, the human conceptual system is metaphorical. They have led many readers to a new recognition of how profoundly metaphors not only shape our view of life in the present but also set up the expectations that determine what life will be in the future. Lakoff argues that in order to persuade a political audience of one side of and argument or another, the facts must be presented through a rhetorical frame. It is argued that, without the frame, the facts of an argument become lost on an audience, making the argument less effective. The rhetoric of politics uses framing to present the facts surrounding an issue in a way that creates the appearance of a problem at hand that requires a solution.' (Lakoff, Wikipedia, the free encyclopedia)

In Why Trump Got the Republican Nomination: It's the Metaphors Drawing Us In, Lakoff states that 'the job of Trump's supporters and other radical Republican extremists is to impose their view of strict father morality in all areas of life. They do not need to name policies, because the Republicans already of hundreds of policies ready to go. They just need to be in complete power. Unconscious thought works by certain basic mechanisms. Trump uses them instinctively to turn people's brains toward what he wants absolute authority, money, power, celebrity.' (Lakoff, Wikipedia, the free encyclopedia)

\subsubsection{Studies by Political Analysts}

Editorials

In his article Media Call out Trump's 'Campaign of Fear' After Convention Speech, Hargis (2016) mentions that Donald Trump has intended to sow fear in America's voters: Fear of uncontrolled crime and terrorism that "threaten our very way of life." Fear of immigrants, including refugees from the civil war in Syria. Fear of Muslims, although instead of the "total and complete shutdown of Muslims entering the United States". Finally, Trump warned that Americans should fear Hillary Clinton, whom he described as a corrupt politician whose legacy as secretary of State amounted to "death, destruction and weakness.

In his article How Donald Trump plays the politics of fear, Zelizer (2015) stated, "Playing to fears can help 
candidates gain attention from the news media and the electorate, and it offers an easy way to depict their opposition as incapable of leading. According to a recent New York Times/CBS News poll, fears of terrorism have boosted Trump's position.

In his article The scariest thing about Trump's primary dominance: The GOP still doesn't understand the monster it created, Parton (2015) mentioned that Trump declared victory with an odd admission of what really turns him on about running for president, when he said, "It's tough, it's nasty, it's mean, it's vicious.... it's beautiful. When one wins, it's beautiful." He is very, very good at being mean, nasty and vicious. "Nobody can say that isn't working for him."

\subsection{Studies on Framing Theory}

In Lakoff: IN Politics, Progressives Need to Frame Their Values, Karlin (2014) stated that framing means, "Communication itself comes with a frame. The elements of the Communication Frame include a message, an audience, a messenger, a medium, images, a context, and especially, higher, level moral and conceptual frames. The choice of language is, of course, vital, but it is vital because language evokes frames - moral and conceptual frames. Frames form a system."

In Framing the issues: Lakoff tells how conservatives use language to dominate politics, Powell (2003) stated that Lakoff points out that Language always comes with what is called "framing". Every word is defined relative to a conceptual framework. If you have something like "revolt", that implies a population that is being ruled unfairly, or assumes it is being ruled unfairly, and that they are throwing off their rulers, which would be considered a good thing. That is a frame.

In his article Media Framing of a Civil Liberties Conflict and Its Effect on Tolerance, Nelson et al. (1997) considered framing to "the process by which a communication source ... defines and constructs a political issue or public controversy" (1997b, p. 567).

In his book Deflating the Elephant: Framed Messages Behind Conservative Dialogue, Lakoff (2009) examines the lexicon of conservative politicians in the U.S. and how phrases such as "pro-life", "no child left behind" and "the war on terror" dominated the national dialogue with polarizing results. Language is influenced by what is known as "framing", meaning every word is connected to a concept. How those concepts are used and repeated have proven to shape ideology, behavior and thought, process.

\section{Method}

\subsection{The Model of the Study}

\subsubsection{Lakoff's LFM}

The study is a psycholinguistic analysis of the Nomination Acceptance Speech of the candidate Donald Trump (Republican) and the Editorials' reactions to his acceptance speech, from major news sources (e.g., Wall Street Journal, New York Times, Washington Post) within the framework of Lakoff's LFM.

\subsection{The Research Questions}

Quantitative research questions:

Q 1: How frequency does Trump use the 'rhetoric of fear' in his political speech?

Qualitative Research questions:

Q 2: Why does Trump use a political 'rhetoric of fear'?

Q 3: What topics does Trump deal with in creating a political 'rhetoric of fear'?

Q 4: What are the parts of Trump's speech that trigger fear in the audience?

Q 5: Does Trump use other stylistic strategies to support using the 'rhetoric of fear'?

\subsection{Research Assumptions}

Framing is used by a political candidate employing his linguistic repertoire to construct his 'rhetoric of fear'.

Frames are powerful rhetorical entities that induce audience to filter their perceptions of the world in particular ways essentially making some aspects of their multi-dimensional reality more noticeable than other aspects.

A political discourse is analyzed using LFM to have an analysis as evidence to the claim that Trump's speech using 'rhetoric of fear' appeals to the audience. Some may respond feeling 'fearful' while others may respond feeling 'protected' or 'heard' that a candidate is listening to their concerns and going to do something about them. 
Audience is a key to the application of LFM since framing of any rhetoric is affecting in moving audience if it is understood who the audience is.

\subsection{Data Collection}

The data of this study is collected from the presidential election speech of the candidate Donald Trump's.

\subsection{Data Analysis}

The study is tackled through a thoroughly linguistic contextual analysis of the presidential election rhetoric from the perspective of LFM perspective in order to get to know how a candidate makes use of the 'rhetoric of fear' to make her argument more persuasive and appealing.

\subsection{Procedures}

Qualitative: Critical discourse analysis for Donald Trump's acceptance speech

a. Language of fear-what is the language? Who is the target in the fear, producing statements ad premises? Why is it effective?

b. Evidence of exaggeration and omission (e.g., what does the candidate misrepresent or not include in order to make his argument more persuasive, appealing, and compelling?).

Quantitative: Count of frequency of particular words and phrases that carry the message of fear.

Provide evidence of the effectiveness of the strategy based on the supporters' responses of each candidate to the acceptance speeches. (Source-editorials in support of Clinton and Trump after their acceptance speeches; consult The Wall Street Journal, New York Times, Washington Post).

Table 1. The analysis of the nomination acceptance speech of the candidate Donald Trump within the framework of LFM

\begin{tabular}{|c|c|c|c|c|c|}
\hline No. & Discourse & Theme & $\begin{array}{l}\text { How the theme is framed } \\
\text { by Trump }\end{array}$ & $\begin{array}{l}\text { The effect of the framing on the } \\
\text { audience }\end{array}$ & Attitude \\
\hline 1 & $\begin{array}{l}\text { we will lead our country } \\
\text { back to safety, prosperity, } \\
\text { and peace. ... But we will } \\
\text { also be a country of law and } \\
\text { order. }\end{array}$ & $\begin{array}{l}\text { - Show his ability to change } \\
\text { the country's political } \\
\text { condition: lack of safety, } \\
\text { prosperity, peace. } \\
\text { - Confirm the necessity of } \\
\text { having law and order. }\end{array}$ & $\begin{array}{l}\text { - Use of contradictory } \\
\text { discourses } \\
\text { - Use of distinct words: } \\
\text { safety, prosperity, peace. } \\
\text { - Repetition of a key } \\
\text { word: 'lead'. } \\
\text { - High frequency of the } \\
\text { use of the obligatory } \\
\text { modal: 'will'. }\end{array}$ & $\begin{array}{l}\text { - "I really do not like Trump's most } \\
\text { offensive comments on Muslims and } \\
\text { immigration, "He's authentic, } \\
\text { - "he is not talking like politicians talk. } \\
\text { Trump's popularity rests on his } \\
\text { approach and delivery, regardless how } \\
\text { ridiculous, offensive, or even untruthful } \\
\text { his statements may be. } \\
\text { - the thought of Trump following } \\
\text { through is scary to many (1). }\end{array}$ & neutral \\
\hline 2 & $\begin{array}{l}\text { To protect us from } \\
\text { terrorism ... We must } \\
\text { abandon the failed policy of } \\
\text { nation building and regime } \\
\text { change that Hillary Clinton } \\
\text { pushed in Iraq, Libya, Egypt } \\
\text { and Syria. Lastly, we must } \\
\text { immediately suspend } \\
\text { immigration from any } \\
\text { nation that has been } \\
\text { compromised by terrorism. }\end{array}$ & $\begin{array}{l}\text { - Show his determination to } \\
\text { change the current political } \\
\text { condition and protect America } \\
\text { from terrorism. }\end{array}$ & $\begin{array}{l}\text { - Repetition of a distinct } \\
\text { emphatic word: } \\
\text { 'Terrorism'. }\end{array}$ & $\begin{array}{l}\text { Donald Trump's acceptance speech } \\
\text { played like a best-of episode of his dark } \\
\text { reality TV primary season. Immigration } \\
=\text { crime = terrorism = political } \\
\text { correctness = economic decline (2). }\end{array}$ & Against \\
\hline 3 & $\begin{array}{l}\text { Any politician who does not } \\
\text { grasp this danger is not fit to } \\
\text { lead our country. }\end{array}$ & $\begin{array}{l}\text { - Confirm the fact that the } \\
\text { country is facing danger and } \\
\text { the current politicians are not }\end{array}$ & $\begin{array}{l}\text { - Use of a striking word: } \\
\text { 'danger'. }\end{array}$ & & \\
\hline 4 & $\begin{array}{l}\text { After fifteen years of wars } \\
\text { in the Middle East, after } \\
\text { trillions of dollars spent and } \\
\text { thousands of lives lost, the } \\
\text { situation is worse than it has } \\
\text { ever been before. }\end{array}$ & qualified to lead it. & $\begin{array}{l}\text { - Use of intertextuality } \\
\text { of scaring facts. }\end{array}$ & & \\
\hline
\end{tabular}


our convention, there will be no lies. We will honor the American people with the truth, and nothing else.

My plan will begin with safety at home-which means safe neighborhoods, secure borders, and protection from terrorism. mothers who have lost their children because our politicians. injustice, no tolerance for government incompetence, no sympathy for leaders who fail their citizens. When I am President, I will work to ensure that all of our kids are treated equally, and protected equally.

The irresponsible rhetoric of our President... has made America a more dangerous environment for everyone.

...determined deliver a better life for the people all across this nation that have been ignored, neglected and abandoned.

I have joined the political arena so that the powerful can no longer beat up on people who cannot defend themselves.

13 The first task for our new administration will be to liberate our citizens from the crime, terrorism, and lawlessness that threatens their communities.

straightforward and honest and is based on lies and myths.

- Confirm the fact that America lacks 'safety.

Show that he is courageous enough to change the country's political condition.
- Use of emphatic phrases: 'safety at home', 'safe neighborhoods', 'secure borders,' and 'protection from terrorism'. - Repetition of synonymous distinct words: safety, secure, and protection.

- Use of distinct phrases: 'crying mothers' 'lost their children'.
Make the American people worried about future and confirm the fact that he is the one who will create safety and justice in America.

- Show how much the people in America have being suffering because of their incompetent politicians.

- Confirm the fact that there are people in America who have being suffering from ignore, neglect, and abandon and determined to change the current political condition of Americans to a better one.

- Show the necessity of the availability of defense for the people who cannot defend themselves.

- Frighten the American people about future confirming the fact that America is afflicted by crime, terrorism and lawlessness.
Use of striking phrases:

'injustice', 'no patience',

'no tolerance',

'government

incompetence', 'no

sympathy'.

- Use a decisive statement: 'When I am President, I will work to ensure that all of our kids are treated equally, and protected equally.'

- Use of distinct phrases: 'irresponsible rhetoric', 'divide us by race and color', 'made America a more dangerous environment for everyone.'

- Use of distinct words: 'determined', 'ignored', 'neglected' and

'abandoned'.

- Use of distinct phrases: 'beat up on people', 'defend themselves'.

- Use of striking words: 'liberate', 'crime', 'terrorism', 'lawlessness' and threatens'. example, and they are right to do so.

But this is the truth that "seriously not literally" gestures to: Identifying a problem in American life-whether it is real, imaginary, or

exaggerated - became synonymous with caring about the people worrying about those things. (3)

Donald Trump's speech can be best summed up as "Be afraid. Be very afraid." Trump was peddling fear at levels we had never seen before. Trump's "dark" speech truly "terrified" him. (8)

"But his core strategy is rooted not only in exploiting the fears of Americans but in heightening them." (9)

Trump put it all together in one scary ball that defined a moment of crisis in the country. Unemployment is falling; the supposedly ignored border is well fortified. (10)

Trump ... will do it. "I alone can fix it," —but still had not come up with a plan for who else could. (11)

Obama largely shied away from using fear as a political weapon,

Critics often excoriated him for his sanguine comments about the state of the war on terrorism. (12)

Trump's voters are looking forward to him bringing back jobs, securing the border, and deporting people. (13)

For Trump to justify scaring us, he needs to be able to deliver on his promise to keep us safe. ... Trump was focused primarily on one thing: making money. (14)
For

For 
14 we have seen continued threats and violence against our law enforcement officials. Law officers have been shot or killed in recent days ..., more police were gunned down ... An attack on law enforcement is an attack on all Americans. Nobody knows the system better than me, which is why I alone can fix it.

In this race for the White House, I am the Law and Order candidate.

This Administration has failed America's inner cities. It's failed them on education. It's failed them on jobs. It's failed them on crime.

my opponent wants Sanctuary Cities. ... Where was the Sanctuary for all the other Americans who have been so brutally murdered, and who have suffered so horribly?

19 Every action I take, I will ask myself: does this make life better for young Americans in Baltimore, Chicago, Detroit, Ferguson who have the same right to live out their dreams as any other child in America? we must also address the growing threats we face from outside the country. A nation in mourning. The damage and devastation that can be inflicted by Islamic radicals has been proven over and over.

22 As your President, I will do everything in my power to protect our LGBTQ citizens from the violence and oppression of a hateful foreign ideology.

we heard from three parents whose children were killed by illegal

immigrants-They are just three brave representatives

- Use of hyponymous words and phrases: 'shot', 'killed', 'attack', 'gunned down', and 'badly injured' under the hypernymous noun 'violence'.

Confirm the fact that he is the only one who will create safety in America.

Make American people worried about future and makes them reject democratics confirming the fact that the reflections of their policy are failure and corruption.

- Confirm the fact that the democratic politicians do not care about people's life and they manipulate the American laws for their own benefits.

Confirms the fact that there are people in America who have being suffering from injustice and shows his determination to change the current political condition of Americans to a better one.

Make the Americans feel worried and anxious about the lack safety and the growing threats their country face.

\section{- Frighten the LGBTQ} citizens about their future and confirm the fact that he is the one who will create safety and defense for them.

\section{- Frighten people about} future and confirms the fact that the reflections of Hillary Clinton s' policy are death, destruction, terrorism and

Trump's inaugural speech painted a

Against

deeply misleading picture: Crime is still relatively low, $\ldots$ unemployment is falling, the supposedly ignored border is well fortified. (15)

Use of synonymous statements: 'Nobody knows the system better than ME'; 'I ALONE can fix it.'

- Use of a striking statement: 'I am the Law and Order candidate'.

- Repetition of a key word: 'failed'.

- Use of an emphatic phrase:

'brutally murdered', 'suffered so horribly.'

- Use rhetorical questions.

- Use of striking words: 'safe', 'threats', and 'defeat'.

- Use of distinct words and phrases: 'A nation in mourning'. 'The damage and devastation', 'savagely murdered'.

- Repetition of an emphatic word 'terrorism'.

- Use of striking phrases: 'my power to protect' 'violence and oppression' 'a hateful foreign ideology'.

- Use of striking phrases: 'illegal immigrants' and 'many thousands who have suffered so gravely.'
What in Trump's background would even suggest that he has any understanding of how to deal with the threats facing our nation? (16)

His strategy has not changed: tap into pre-existing racism, amp it up with rhetoric, with promises of mass deportations and a huge wall, and then redirect that energy to his campaign. (17).

Trump is different. His approach is to seed fear, not assuage it. (18)

no President has weaponized fear quite like Trump. He is an expert at playing to the public's phobias. He shapes public opinion by emphasizing dangers - both real and imaginary - that his policies purport to fix. (19)

The American people are afraid, ... "That's what the President's reflecting. Unlike past Democrats and Republicans, President Obama largely shied away from using fear as a political weapon.” (20)

Trump exaggerates the threat. The murder rate is actually down sharply from peak levels a generation ago. (21)

Trump's speech won't help him - that optimism beats pessimism, that hope beats fear, that light beats dark. ... Trump is also fighting demographics. His angry, dark campaign has gotten him this far. (22)

"His formula is very clean and uncomplicated: Be very, very afraid. And I am the cure." Fear has been a fixture of Trump's oratory since the start of his campaign, which began with
Against

Against

Against

Against

Against

Against

Against 
of many thousands who have suffered so gravely.

These wounded American families have been alone. But they are alone no longer. Tonight, this candidate and the whole nation stand in their corner to support them, to send them our love, and to pledge in their honor that we will save countless more families from suffering the same awful fate. parent who dreams for their child, and every child who dreams for their future, I say these words to you tonight: I'm with you, I will fight for you, and I will win for you.

\section{weakness intending to}

underestimate her policy for the sake of making the American people reject her as a president. Make the Americans feel worried and anxious about the safety and the growing threats their country face and shows his ability to change the country's political condition.

- Intend to evoke the fear and worries of parents and of youths towards the life of their children.

\section{State the fact that America lacks strength, proud, safety, and greatness in the current time, but when he becomes president, he will regain them}

all. an attack on Mexican immigrants.

His inaugural address was a dark rumination on "American carnage":

- Use of striking phrases: 'wounded American families' and 'suffering the same awful fate.'

- Use of juxtaposition:

'violence'\# peace.

- Repetition of emphatic words: 'violence' and 'illegal'.

- Use striking words: 'fight' and 'win'.

- He is extremely good at validating people's fears, but he does not offer any suggestions for how they can be ameliorated. (24)
Use of striking phrases:

'Strong Again' ... 'Proud

Again'... 'Safe Again'....

'Great Again'.
Again. And We Will Make

America Great Again.

Note. (18), (19), (20) and (22): Altman, A. (2017). No president has spread fear like Donald Trump. Time.

(15) and (17): Ball, M. (2016). Trump's dark comfort is a way to validate his supporters' fears. The Atlantic's Politics \& Policy Daily.

(20): Brammer, J. P. (2016). Here's why I'm terrified of Donald Trump. Linda Sarsour, Jessica Valenti, Syreeta McFadden, Trevor Timm. The Guardian.

(2) and (13): Dara, L. (2017). Trump's rhetoric only works when it's dark and scary. Why phrases like "American carnage" sound so un-American. Vox.

(10) (11): de Moraes, L. (2016). Trump Scares Everyone for Their Own Good In RNC Nom Acceptance Speech. The Deadline Hollywood.

(1): Geiger, D. (2016). How Donald Trump Is Using Social Media to Spread Fear-And Get Elected. Teen Vogue. Retrieved from http://works.bepress.com/kari_hong/107/

(24): Jill, P., \& Weinstein. (2017). He's already let America down: the reaction to Trump's first speech as president. The Guardian.

(22): Jonathan, C. (2016). That was a Very Scary Speech Donald Trump Just Gave. Fear and loathing in Cleveland. HUFFPOST. POLITICS.

(14)(16): Obeidallah, D. (2016). Trump Can Scare You, but He Can't Keep You and Your Family Safe. HUFFPOST.

(10): Sandys, T. (2016). What it looks like at the Republican National Convention on Day 4. The Washington Post.

\section{The Results and Discussion}

Frames are powerful rhetorical entities that induce audience to filter their perceptions of the world in particular ways essentially making some aspects of their multi-dimensional reality more noticeable than other aspects.

Audience is a key to the application of LFM since framing of any rhetoric is affecting in moving audience if it is understood who the audience is.

Communication through the functioning of a political discourse is a dynamic process of mutual recognition of a candidate and her/his audience's motivation.

A political discourse is analyzed using LFM to have an evidence to the claim that a candidate's speech using 'rhetoric of fear' appeals to the audience. Some may respond feeling 'fearful' while others may respond feeling 'protected' or 'heard' that a candidate is listening to their concerns and going do something about them.

A political candidate employs his linguistic repertoire to construct his rhetoric of fear using framing. He frames his theme regarding the choice of vocabulary, semantic relations and syntactic structures, and that these frames are consciously or unconsciously principled and systematic: the choice of vocabulary, the use of distinct words: safety, prosperity, peace, generosity, warmth, and the repetition of a key word: 'lead', as in, 1; the use of striking word: 'danger', as in, 2; 9; the use of juxtaposition: Lies \# truth, as in, 5; the use of intertextuality of scaring 
facts, and 'wars in the Middle East', as in, 4.

The main topics that the political candidate of the study dealt with in creating a political 'rhetoric of fear' are the following:

- Shows his ability to change the country's political condition: lack of safety, prosperity, peace, generosity and warmth.

- Shows his mechanism of protecting America from terrorism to reflect his ability to be the president of America.

- Confirms the fact that the country is facing danger and the current politicians are not qualified to lead it.

- Intends to evoke the fear and worries of parents and of youths towards the life of their children.

For the sake of making the American people reject Hillary Clinton to be a president, he confirms the following facts:

- the reflections of Hillary Clinton's policy are 'poverty', 'violence at home', crime, lawlessness, 'war', death, terrorism, weakness, 'destruction abroad', illegal acts and lies that have put America at risk and created corruption.

- he democrats' policy is not straightforward and not honest and is based on lies and myths.

- the democratic politicians do not care about people's suffer and do not enforce the American laws, but they manipulate it for their own benefits.

- there are people in America who have being suffering from ignorance, neglect, and abandon.

- the law and order must be applied for the sake of creating justice, safety and prosperity in America and he is the one who will do it.

- the necessity of the availability of defense for the people who cannot defend themselves.

A critical discourse analysis (CDA) does not solely analyze and interpret a discourse, but also explains them. Therefore, an awareness of unequal relations of power in a political context, involving hierarchical dimensions of domination and subordination, helps in realizing how language contributes to the domination of some people by others, as in, 1, 6, 7, 11, 14 and 25 .

CDA reflects how social relations of power are framed in a discourse. In the data analysis of the study, the focus has been given to the power of a candidate and how he frames his speech in the force potential of the linguistic strategies he uses in order to show his power potential that helps him dominate the political context and make changes, as has been shown in the following: the use of contradictory discourses, as in, 1 ; the use of distinct words, as in, 1; the use of distinct clauses, as in, 9; the use of repetition of a key word, as in, 1, 2, 16, 18, 24, 21, 22,23 ; the use of repetition of synonymous distinct words, as in, 1,15 ; the use of repetition of an emphatic word, as in, 2, 14, 24; the use of an emphatic statements, as in, 17; the use of the obligatory modal: 'will', as in, 1, 15; the use of the obligatory modal: 'must', as in, 2; the use of a striking word, as in, 11, and 22; the use of striking phrases, as in, 2, 24; the use of a striking statement, as in, 16, 23; the use of synonymous statements, as in, 11; the use of synonymous modifiers, as in, 11; make a comparison between America in the present time and America in the time during which Hillary Clinton was in charge of America's foreign policy confirming the fact that both periods are bad but the present time is worse, as in, 4; the use of intertextuality, as in, 4; the use of hyponymous words and phrases, as in, 14; the use of decisive statements, as in, 9 ; the use rhetorical questions, as in, 19; the use of juxtaposition, as in, 24.

\section{Conclusion}

CDA of a political discourse makes it possible to see how the institutionalized use of strategy language has implications: some of these emerge from the genre itself while others derive from situation, specific choices. In any case, one thing is certain: strategy documents should not be treated as just any texts, but understood as powerful devices through which specific objectives, values and ideologies are promoted and legitimated.

\section{References}

Hargis, C. (2016). Media Call out Trump's “Campaign of Fear” After Convention Speech. LA Times.

Kaid, L. (1981). Political advertising. In D. Nimmo \& K. R. Sanders (Eds.), Handbook of political communication (pp. 249, 271). Beverly Hills, CA: Sage.

Kaid, L. (1994a). Measuring candidates with semantic differentials. In K. Hackers (Ed.), Candidate images in presidential election campaigns (pp. 111, 127). New York: Praeger. 
Kaid, L. (1994b). Political advertising in the 1992 campaign. In R. E. Denton Jr. (Ed.), The 1992 presidential campaign: A communication perspective (pp. 111, 127). Westport, CT: Praeger.

Karlin, M. (2014). George Lakoff: IN Politics, Progressives Need to Frame Their Values. Truthout|Interview.

Lakoff, G. (2002). Moral Politics: How Liberals and Conservatives Think. Chicago: The University of Chicago Press. https://doi.org/10.7208/chicago/9780226471006.001.0001

Lakoff, G. (2004). Don't Think of an Elephant: Know Your Values and Frame the Debate. Chelsea Green Publishing.

Lakoff, G. (2006). Whose Freedom? The Battle over America's Most Important Idea. Farrar, Straus and Giroux.

Lakoff, G. (2008). The Political Mind: Why You Can't Understand 21st Century American Politics with an 18th Century Brain. Viking Adult.

Lakoff, G. (2009). Deflating the Elephant: The Framed Messages Behind Conservative Dialogue. Chicago: University of Chicago Press.

Lakoff, G. (2016). Why Trump Got the Republican Nomination: It's the Metaphors Drawing Us in. In Advice Goddess Blog.

Lakoff, G., \& Johnson, M. (1980). Metaphors We Live By. Chicago: University of Chicago Press.

Lakoff, G., \& Johnson, M. (1999). Philosophy in the Flesh: The Embodied Mind and its Challenge to Western Thought. Basic Books Group.

Lakoff, G., \& Turner, M. (1989). More Than Cool Reason. Chicago: University of Chicago Press. https://doi.org/10.7208/chicago/9780226470986.001.0001

Lakoff, G., \& Wehling, E. (2012). The Little Blue Book: The Essential Guide to Thinking and Talking Democratic. Free Press.

Nelson, T. E., Clawson, R. A., \& Oxley, Z. M. (1997). Media Framing of a Civil Liberties Conflict and Its Effect on Tolerance. American Political Science Review, 91(3), 567. https://doi.org/10.2307/2952075

Parton, H. D. (2016). The scariest thing about Trump's primary dominance: The GOP still doesn't understand the monster it created. Salon.

Powell, B. A. (2003). Framing the issues: UC Berkeley professor George Lakoff tells how conservatives use language to dominate politics. News Center, University of California, Berkeley News.

Zelizer, J. (2015). How Donald Trump plays the politics of fear. CNN Opinion.

\section{Copyrights}

Copyright for this article is retained by the author, with first publication rights granted to the journal.

This is an open-access article distributed under the terms and conditions of the Creative Commons Attribution license (http://creativecommons.org/licenses/by/4.0/). 